\title{
Pengembangan Materi Bangun Ruang Sisi Datar Sebagai Bagian dari Persiapan Calon Guru Sekolah Dasar
}

\author{
S. Satrianawati \\ Pendidikan Guru Sekolah Dasar, Fakultas Keguruan dan Ilmu Pendidikan, Universitas Ahmad \\ Dahlan. Jl. Kapas 9, Semaki, Umbulharjo, Yogyakarta 55166, Indonesia \\ Email: satrianawati@pgsd.uad.ac.id, Telp: (+62274) 563515 \\ Received: 29 October 2016; Revised: 9 March 2017; Accepted: 8 May 2017
}

\begin{abstract}
Abstrak
Penelitian ini bertujuan untuk mengembangkan bahan ajar materi bangun ruang sisi datar sebagai bagian dari persiapan calon guru sekolah dasar. Penelitian ini merupakan jenis penelitian pengembangan pendidikan (educational research and development) sehingga yang diharapkan adalah adanya produk berupa modul berisi materi bangun ruang sisi datar yang dapat digunakan sebagai pedoman untuk proses pembelajaran. Pengembangan produk dilakukan dengan cara menganalisis kebutuhan, mendesain pengembangan, memproduksi/ mengembangkan bahan ajar, melakukan evaluasi produk, dan melakukan uji coba produk akhir dalam skala kecil dan skala besar kemudian dilanjutkan dengan proses produksi dan disebarluaskan. Penilaian produk bahan ajar bangun ruang sisi datar menunjukkan hasil yang positif. Hasil penilaian ahli materi dan ahli pembelajaran hasil pengembangan termasuk dalam kategori "sangat baik" yaitu 4,8 dan 4,3. Sedangkan hasil uji coba dalam skala kecil menunjukkan bahwa frekuensi kelayakan produk untuk dikembangkan sebesar 4,71. Adapun rerata nilai pretestt adalah 77,5 dan rerata nilai posttest adalah 85,83 . Adapun untuk uji coba produk dalam skala besar menunjukkan bahwa sebanyak $47,72 \%$ berada dalam kategori cukup baik dan $25 \%$ berada dalam kategori baik dan $6,81 \%$ berada pada kategori sangat baik. Jadi pengembangan produk bahan ajar bangun ruang sisi datar perlu untuk diproduksi dan disebarluaskan untuk peningkatan mutu dan kualitas pendidikan.
\end{abstract}

Kata Kunci: bahan ajar, bangun ruang sisi datar

\section{The Development of Three-Dimensional Geometry to Prepare for Prospective Elementary School Teacher}

\begin{abstract}
This research aims to develop learning materials, three-dimensional geometry to prepare for prospective primary school teachers. This research is the educational research and development. so that the product is expected to be the module containing the material three-dimensional geometry which can be used as a guide to the learning process. Product development is carried out by means of analyzing needs, designing development, producing/developing learning materials, evaluate products, and perform a test run of the final products in small scale and large scale then continued with the production process and disseminated. Product assessment materials of three-dimensional geometry show positive results. The results of the expert assessment of the material and expert learning outcomes development included in the category of "excellent" 4.8 and 4.3. While the results of a test on a small scale show that the frequency of the feasibility of the product to be developed of 4.71. As for the average value of the pretestt is 77.5 and average values for the posttest is 85.83. the value test products in large scale show that as much as $47.72 \%$ are in a category is enough and $25 \%$ are in the category of good and $6.81 \%$ are on an excellent category. Product development learning materials three-dimensional geometry need to be produced and disseminated to quality improvement and quality education.
\end{abstract}

Keywords: learning materials and Three-dimensional geometry

How to Cite: Satrianawati, S. (2017). Pengembangan materi bangun ruang sisi datar sebagai bagian dari persiapan calon guru sekolah dasar. Jurnal Riset Pendidikan Matematika, 4(1), 108-119. doi:http://dx.doi.org/10.21831/jrpm.v4i1.11469

Permalink/DOI: http://dx.doi.org/10.21831/jrpm.v4i1.11469 


\section{Jurnal Riset Pendidikan Matematika, 4 (1), 2017 - 109}

S. Satrianawati

\section{PENDAHULUAN}

Proses pembelajaran merupakan sesuatu hal yang berkesinambungan dan berlangsung sepanjang hayat. Pembelajaran dengan hasil yang memuaskan membutuhkan proses yang maksimal. Untuk melaksanakan proses yang maksimal seorang guru ataupun dosen perlu menyiapkan bahan ajar yang dapat menjadi pedoman atau pegangan bagi mahasiswa maupun dosen. Bahan ajar yang dimaksudkan dapat menjadi suatu mediasi bagi dosen untuk materi yang akan diberikan kepada mahasiswa.

Pentingnya bahan ajar dipersiapkan oleh dosen karena perlunya memperhatikan kondisi mahasiswa yang mendapatkan pengetahuan dari berbagai sumber. Banyaknya pengetahuan yang diperoleh mahasiswa maka untuk menyamakan bahan atau materi yang akan dipelajari sehingga persiapan bahan ajar perlu untuk dipersiapkan. Bahan ajar yang diberikan oleh dosen tentunya telah terangkum dalam RPM yang dibuat.

Pentingnya bahan ajar ini, ternyata belum sepenuhnya dipersiapkan oleh dosen sehingga ada beberapa mahasiswa yang belum tahu materi yang akan dipelajari karena tidak memiliki pegangan. Bahkan ada beberapa mahasiswa yang tahu materi yang akan dipelajari ketika proses perkuliahan. Padahal untuk materi setiap pertemuan telah diberikan yang termuat dalam RPS. Hal ini menunjukkan bahwa masih ada ketidak pedulian mahasiswa terhadap materi yang akan disampaikan sehingga terkesan tidak tahu materi dan tidak punya bahan untuk menjadi bacaan. Bacaan untuk materi perkuliahan yang disampaikan belum dipersiapkan dan diberikan kepada mahasiswa dalam bentuk buku ataupun modul. Ini belum dilakukan pada perkuliahan matematika lanjut. Padahal perkuliahan ini memiliki tujuan mengutamakan penanaman konsep kepada para mahasiswa dari materi pembelajaran yang ada dalam mata kuliah matematika lanjut. Salah satu diantara materinya adalah bangun ruang. Oleh karena itu, peneliti tertarik untuk melakukan penelitian dan pengembangan dengan judul pengembangan materi bangun ruang sisi datar sebagai bagian dari persiapan calon guru sekolah dasar. Penelitian yang relevan dengan penelitian ini adalah penelitian yang dilakukan oleh Matutina, (2014) dengan judul "Pengembangan Lembar Kerja Siswa Mata Pelajaran Matematika Materi Bentuk Aljabar Dengan Pendekatan Kontekstual Untuk Siswa SMP Kelas VII"

\section{METODE}

\section{Model Pengembangan}

Penelitian ini merupakan jenis penelitian dan pengembangan pendidikan (educational research end development) bertujuan untuk mengembangkan modul materi bangun ruang sisi datar sebagai Bagian dari persiapan calon Guru Sekolah Dasar. Gall, Gall, \& Borg (2007, p. 589) menyatakan bahwa "research and development is an-industry-based development model in which the findings of research are used to design new products and procedures, which then are systematically field tested, evaluated, and refined until they meet specified criteria of effectiveness, quality, or similar standards". Maksudnya bahwa penelitian pengembangan merupakan sebuah mode usaha pengembangan untuk menemukan produk dengan desain baru yang terlebih dahulu melalui proses uji lapangan, evaluasi, dan revisi sebelum diproduksi secara masal. Lebih lanjut Gall et al. (2007, p. 772) menyatakan bahwa "education research and development $(\mathrm{R} \& \mathrm{D})$ is a process used to develop and validate educational products". Maksudnya bahwa penelitian pendidikan dan pengembangan adalah suatu proses untuk mengembangkan dan memvalidasi produkproduk pendidikan.

Produk yang dikembangkan tidak selalu berbentuk benda atau perangkat keras (hardware), seperti buku, alat bantu pembelajaran di kelas atau laboratorium, tetapi perangkat lunak (software), seperti multmedia program komputer. Dalam pelaksanaan penelitian dan pengembangan ini, ada 3 metode yang digunakan, yaitu: (1) metode deskriptif; (2) metode evaluatif; dan (3) metode eksperimental. Metode deskriptif digunakan pada penelitian awal untuk mengumpulkan data dari kondisi yang ada. Metode evaluatif digunakan untuk mengevaluasi proses uji coba produk yang dikembangkan. Metode eksperimen digunakan untuk menguji kelayakan dan keefektifan dari produk yang dihasilkan (Sukmadinata, 2013, p. 167). Penelitian yang dikembangkan dalam penelitian ini berupa buku ajar berupa materi tentang bangun ruang sisi datar sebagai Bagian dari persiapan calon Guru Sekolah Dasar. Penelitian pengembangan yang dilakukan digunakan untuk memecahkan masalah praktis dan mengkontribusikan hasil penelitian yang dikembangkan untuk kemajuan pendidikan. Oleh karena itu, berdasarkan teori Borg \& Gall dapat dihasilkan sebuah model pengembangan pembelajaran yang lebih seder- 
hana untuk diterapkan. Adapun model pengembangan dapat digambarkan sebagai berikut:

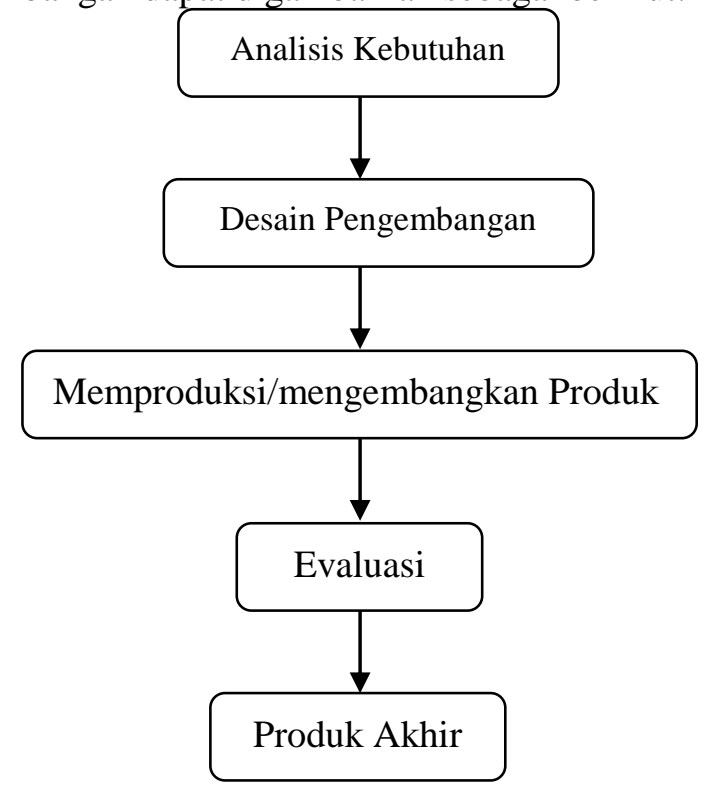

Gambar 1. Model Pengembangan Bahan Ajar pada materi Bangun Ruang Sisi Datar

\section{Prosedur Pengembangan}

Langkah-langkah pengembangan atau prosedur pengembangan yang didapatkan dari model pengembangan Dick \& Carrey (Gall et al., 2007) adalah sebagai berikut: (1) analisis kebutuhan. Tahap ini bertujuan untuk mendapatkan informasi yang relevan terkait dengan pengembangan materi bangun ruang sisi datar sebagai Bagian dari persiapan calon guru sekolah dasar. Analisis ini meliputi analisis karakteristik mahasiswa, studi pustaka dan observasi lapangan untuk menemukan permasalahan yang ada terkait bangun ruang; (2) desain pengembangan. Setelah melakukan analisis karakteristik mahasiswa, studi pustaka dan observasi lapangan, maka informasi yang telah terkumpul dijadikan acuan sebagai pengembangan produk; (3) memproduksi/mengembangkan bahan ajar. Tahap ini merupakan sebuah rangkaian proses produksi untuk menghasilkan rancangan modul bahan ajar mata kuliah matematika lanjut materi bangun ruang sisi datar sebagai Bagian dari persiapan calon guru sekolah dasar pada tahap awal; (4) evaluasi. Tahap ini merupakan tahap evaluasi produk. Produk yang telah dikembangkan divalidasi oleh ahli yaitu ahli materi dan ahli pembelajaran. Apabila ahli materi dan ahli pembelajaran menyatakan bahwa produk yang telah dibuat sudah layak untuk diuji coba di lapangan, maka peneliti kemudian melanjutkan uji coba produk. Uji coba akan dilakukan secara bertahap, yaitu mulai dari uji coba perorangan, uji coba skala kecil, dan uji coba lapangan/skala besar. Adapaun tujuan akhir dari evaluasi ini adalah mendapatkan produk akhir yang siap disebarluaskan di masyarakat; dan (5) Produk akhir. Tahap ini merupakan tahap dimana produk yang telah diuji cobakan diproduksi dan disebarluaskan. Subjek uji coba atau responden yang terlibat dalam penelitian ini adalah mahasiswa calon guru sekolah dasar pada Prodi Pendidikan Guru Sekolah Dasar Universitas Ahmad Dahlan semester III. Data yang diperoleh dalam penelitian ini merupakan data deskriptif kualitatif yang digunakan sebagai dasar untuk menetapkan kelayakan bahan ajar yang dikembangkan. Data deskriptif kualitatif didapat dari ahli materi, ahli pembelajaran, dan mahasiswa.

Instrumen yang digunakan dalam mengumpulkan data pada penelitian ini berupa lembar validasi ahli dan anket untuk mahasiswa. Data hasil penelitian ini adalah berupa tanggapan ahli materi, ahli pembelajaran, dan mahasiswa terhadap kelayakan produk yang dikembangkan ditinjau dari aspek materi dan aspek pembelajaran. Data berupa komentar, saran perbaikan dan hasil pengamatan peneliti selama proses uji coba dianalisis secara deskriptif dan disimpulkan sebagai masukan untuk memperbaiki atau merevisi produk yang telah dikembangkan. Sedangkan tanggapan ahli materi dan ahli pembelajaran berupa data skor yang diperoleh melalui angket, dianalisis secara deskriptif kuantitatif dengan teknik presentasi dan kategorisasi.

Langkah-langkah yang digunakan untuk menentukan kriteria kelayakan produk yang dikembangkan yaitu dengan mengkonvensi skor yang diperoleh menjadi data kuantitatif. Data yang diperoleh dari angket mahasiswa diubah menjadi data interval.

Adapun angket yang diberikan terdiri atas lima pilihan untuk memberikan tanggapan tentang produk yang dikembangkan, yaitu sangat baik (5), baik (4), cukup (3), kurang (2), dan sangat kurang (1). Seandainya tanggapan siswa sangat baik pada butir pertanyaan-pernyataan, maka skor butir tersebut sebesar " 5 " demikian seterusnya. Skor yang diperoleh kemudian dikonversikan menjadi data kuantitatif. Kelayakan modul bahan ajar matematika lanjut materi bangun ruang sisi datar sebagai bagian dari persiapan calon guru sekolah dasar ditinjau dari ahli pembelajaran dan dari ahli materi yang dinyatakan dengan angka berskala 1-5. Untuk mencari skor rata-rata (rerata skor) dalam 
memberikan penilaian terhadap produk yang telah dikembangkan digunakan rumus:

$$
x_{i}=\frac{\sum i}{N}
$$

Keterangan:

$x_{i}=$ Skor rata-rata

$\sum x_{i}=$ Jumlah Skor

$N$ = Jumlah Responden

\section{HASIL DAN PEMBAHASAN}

\section{Pembelajaran Matematika}

Kidd \& Czerniawski (2010, p. 196) menjelaskan bahwa "learning processes are seen to involve the manipulation of bits and pieces of greater whole using puzzles and problem-solving and applying previous knowledge". Proses pembelajaran merupakan manipulasi yang melibatkan pemanfaatan kebingungan lebih besar dan pemecahan masalah dan melibatkan pengetahuan sebelumnya. Adapun Chambers \& Timlin (2013, p. 8) mengatakan bahwa "mathematics characterized as a tool for solving problems, the underpinning of scientific and technological study and providing ways to model real situation". Pendapat ini mengandung makna bahwa matematika dicirikan sebagai alat untuk memecahkan masalah, fondasi penelitian ilmiah dan teknologi, serta memberikan cara untuk model situasi nyata. Jadi, pembelajaran matematika merupakan proses pemecahan masalah yang dijadikan dasar bagi penelitian. Hal ini menunjukkan bahwa materi pembelajaran dalam matematika memiliki sesuatu yang khas sehingga menjadi acuan bagi pembelajaran yang lain.

Lebih lanjut, Satrianawati (2015, p. 31) matematika merupakan ilmu pengetahuan yang tidak hanya menjadi pelajaran sekolah tetapi juga menjadi bagian terbesar perkembangan peradaban kehidupan manusia. Perkembangan peradaban manusia diperoleh melalui pembelajaran matematika. Pembelajaran matematika di sekolah mengantarkan siswa berpikir lebih logis dan konsisten. Oleh karena itu, hakikat matematika sangat meluas hingga, sehingga dibutuhkan pemahaman tentang matematika dalam kehidupan sehari-hari. Hal ini dijelaskan dalam The National Council of Teachers of Mathematics (2000, p. 4): (1) mathematics for life, maksudnya dengan mengetahui matematika dapat memuaskan dan memberdayakan pribadi seseorang. Artinya ada kepuasan tersendiri memahami matematika dalam pribadi seseorang; (2) mathematics as a part of cultural heritage, maksudnya bahwa matematika merupakan salah satu prestasi budaya dan intelektual terbesar manusia, dan warga negara harus mengembangkan apresiasi dan pemahamannya, termasuk aspek estetika dan bahkan rekreasi; hal ini juga dijelaskan oleh Manfaat (2010, p. 11) bahwa "matematika adalah suatu disiplin ilmu yang muncul dari sebuah proses peradaban manusia yang sangat panjang di bumi ini”. Artinya matematika telah sangat erat dengan kehidupan sehari-hari; (3) mathematics for the workplace, maksudnya matematika diperlukan di tempat kerja maupun di bidang profesional lainnya mulai dari kesehatan hingga desain grafis. Hal ini menunjukkan adanya komponen matematika yang selalu ada dalam kegiatan yang dilakukan sehari-hari; dan (4) mathematics for the scientific and technical community, maksudnya semua karir memerlukan dasar pengetahuan matematika, walaupun banyak siswa yang mengejar jalur pendidikan untuk mempersiapkan diri bekerja seumur hidup sebagai matematikawan, statistik, insinyur dan ilmuwan.

\section{Bahan Ajar Modul}

Bahan ajar merupakan pegangan untuk pembelajaran yang dijadikan acuan ataupun pedoman. Bahan ajar atau teaching material terdiri atas dua kata yaitu teaching yang artinya mengajar dan material yang berarti bahan. Berdasarkan hakikat pembelajaran matematika maka bahan ajar dalam matematika membutuhkan sesuatu persiapan yang menarik sebelum diajarkan kepada mahasiswa.

Bahan yang dimaksud bisa berupa bahan tertulis maupun bahan tidak tertulis. Bahan ajar memungkinkan siswa dapat mempelajari suatu kompetensi atau kompetensi dasar secara runtut dan sistematis sehingga secara akumulatif mampu menguasai semua kompetensi secara utuh dan terpadu. Bahan ajar memiliki peran penting dalam proses pembelajaran untuk peserta didik maupun guru. Berikut ini merupakan fungsi dari bahan ajar menurut Depdiknas (2008, pp.6-7), yaitu: (a) Pedoman bagi guru sebagai petunjuk yang akan mengarahkan semua aktivitasnya dalam proses pembelajaran dan sebagai substansi kompetensi yang seharusnya diajarkan kepada siswa; (b) Pedoman bagi siswa sebagai petunjuk yang akan mengarahkan semua aktivitasnya dalam proses pembelajaran dan sekaligus sebagai substansi kompetensi yang seharusnya dipelajari/ dikuasainya; dan (c) Alat evaluasi pencapaian/penguasaan hasil pembelajaran. 
Berdasarkan teknologi yang digunakan, bahan ajar dapat dikelompokkan menjadi empat kategori yaitu: (a) bahan cetak (printed) antara lain handout, buku, modul, lembar kerja siswa, brosur, leaflet, wallchart, foto/ gambar, model/ maket; (b) bahan ajar dengar (audio) seperti kaset, radio, piringan hitam, dan compact disk audio; (c) bahan ajar pandang dengar (audio visual) seperti video compact disk, film; dan (d) bahan ajar interakatif (interactive teaching material) seperti compact disk interaktif. Beberapa jenis bahan ajar tersebut sangat beragam, maka pengajar dapat memilih salah satu atau beberapa dari jenis-jenis di atas untuk dapat digunakan dalam mengembangkan bahan ajar.

Panduan mengembangkan bahan ajar (Depdiknas, 2008, p.9) terdapat sejumlah manfaat yang dapat diperoleh apabila seorang guru mengembangkan bahan ajar sendiri, yaitu: (a) diperoleh bahan ajar yang sesuai tuntutan kurikulum dan sesuai dengan kebutuhan belajar siswa saat belajar; (b) siswa maupun guru tidak lagi tergantung kepada buku teks yang terkadang sulit untuk diperoleh; (c) bahan ajar menjadi lebih kaya karena dikembangkan dengan menggunakan berbagai referensi yang menunjang materi; (d) menambah khasanah pengetahuan dan pengalaman guru dalam menulis bahan ajar; (e) bahan ajar akan mampu membangun komunikasi pembelajaran yang efektif antara guru dengan siswa karena siswa akan merasa lebih percaya kepada gurunya. Bahan ajar yang bervariasi akan mendapatkan bermanfaat dalam kegiatan pembelajaran menjadi lebih menarik. Siswa juga akan mendapatkan kemudahan dalam mempelajari setiap kompetensi yang harus dikuasainya. Bahan ajar membuat siswa akan lebih banyak mendapatkan kesempatan untuk belajar secara mandiri dan mengurangi ketergantungan terhadap kehadiran guru.

\section{Kriteria Penilaian Kualitas Bahan Ajar}

Setiap produk bahan ajar yang sudah jadi harus dinilai kualitasnya dengan kriteria yang telah ditentukan. Berikut ini akan diuraikan aspek-aspek yang harus dipenuhi dalam menyusun bahan ajar menurut Depdiknas (2008, p.8) antara lain: (1) aspek kelayakan isi yaitu: (a) kesesuaian dengan standar kompetensi dan kompetensi dasar; (b) kesesuaian dengan perkembangan anak; (c) kesesuaian dengan kebutuhan bahan ajar; (d) kesesuaian dengan materi pembelajaran; (e) Manfaat untuk penambahan wawasan; dan (f) kesesuaian dengan moral dan nilai-nilai sosial. (2) dari segi aspek kebahasaan yaitu: (a) keterbacaan; (b) kejelasan informasi; (c) kesesuaian dengan kaidah bahasa Indonesia yang baik dan benar; (d) pemanfaatan bahasa secara efektif dan efisien (jelas dan singkat). (3) dari aspek penyajian yaitu: (a) kejelasan tujuan (indikator) yang ingin dicapai; (b) urutan sajian; (c) pemberian motivasi, daya tarik; (d) interaksi (pemberian stimulus dan respon); dan (e) Kelengkapan informasi.

Pembelajaran selalu ada interaksi. Interaksi dilakukan untuk memberikan penanaman konsep. Untuk interaksi bisa antara dosen dan mahasiswa dengan mediasi media, alat peraga maupun bahan ajar. Interaksi yang dilakukan dapat langsung maupun tidak langsung. Misalnya dengan tidak bertemu dosen pengampu matematika tetapi mahasiswa dapat berinteraksi dengan bahan ajar matematika. Olehnya itu, pembelajaran matematika membutuhkan persiapan yang baik dari dosen. Bahwa belajar matematika melalui bahan ajar yang tersusun dengan baik maka konsep-konsep matematika bisa tersampaikan dan dipahami oleh mahasiswa.

\section{Analisis Produk yang akan dikembangkan (Analisis Kebutuhan)}

Langkah pertama yaitu analisis kebutuhan pengembangan. Langkah ini dilakukan untuk mendapatkan informasi sejauh mana pengembangan produk bahan ajar materi bangun ruang sisi datar dibutuhkan dalam pembelajaran. Analisis kebutuhan dilakukan dengan studi pendahuluan yang terdiri atas kegiatan observasi pembelajaran dan wawancara dengan mahasiswa. Berdasarkan studi pendahuluan dan wawancara yang dilakukan, pelaksanaan pembelajaran dalam membahas materi bangun ruang sisi datar masih belum mempunyai pegangan untuk dijadikan bahan diskusi, sehingga tidak terdapat materi pembelajaran yang mesti diskusikan, dan proses pembelajaran yang hanya berdasarkan pembelajaran tanpa pemusatan topik, sehingga kebutuhan yang mestinya terpenuhi dalam proses pembelajaran menjadi kajian yang melandasi adanya pengembangan/produksi bahan ajar materi bangun ruang sisi datar. Observasi dalam proses pembelajaran yang dilakukan dalam pelaksanaan pembelajaran masih cenderung berpusat pada guru/dosen.

Ha tersebut ditunjukkan pada pembelajaran yang dilakukan lebih mengarah pada pemberian pengetahuan secara ekspositorik atau hanya dari guru/dosen ke peserta didik. Dosen 
menjelaskan materi tentang bangun ruang sisi datar, sedangkan mahasiswa, hanya menunggu tulisan/catatan dosen, tanpa buku paket ataupun buku penunjang pembelajaran lainnya. Metode yang digunakan dalam proses pembelajaran masih didominasi dengan metode ceramah sehingga pembelajaran masih berlangsung satu arah dari dosen ke mahasiswa.

Hasil observasi dan studi pendahuluan menunjukkan adanya kebutuhan yang mendesak untuk materi pembelajaran bangun ruang sisi datar untuk digunakan dalam proses pembelajaran. Oleh karena itu, untuk menyamakan persepsi dan menjadi bahan diskusi diperlukan pengembangan/produksi bahan ajar materi bangun ruang sisi datar yang didasarkan pada capaian kompetensi mahasiswa sebagai calon guru sekolah dasar.

\section{Mendesain Pengembangan}

Langkah kedua dalam penelitian ini adalah mendesain pengembangan berupa perancangan produk yang akan dikembangkan. Hasil perancangan produk bahan ajar materi bangun ruang sisi datar adalah tersusunnya materi/ bahan ajar untuk dijadikan pegangan mahasiswa dalam perkuliahan matematika lanjut. Bahan ajar mata kuliah matematika lanjut dengan Materi bangun ruang sisi datar yang dirancang adalah sebagai berikut: Hakikat bidang banyak, kubus, balok, prima, dan limas. Adapun sub-sub materinya, yaitu unsur-unsur bangun ruang sisi datar, sifat-sifat bangun ruang sisi datar, jaringjaring bangun ruang, luas permukaan bangun ruang dan volume bangun ruang.

Bahan ajar yang dikembangkan dalam penelitian dilengkapi dengan soal-soal latihan yang digunakan untuk mengukur kemampuan setelah mempelajari setiap materi yang dijabarkan. Selain itu, desain pengembangan produk terdiri atas: (a) bagian awal: pada bagian awal ini terdiri atas petunjuk penggunaan modul bahan ajar mata kuliah. Bagian awal bertujuan untuk memberikan informasi petunjuk penggunaan modul/bahan ajar; (b) judul: judul menampilkan gambaran materi yang dibahas dalam modul/bahan ajar. Dari judul mahasiswa akan timbul gambaran isi buku secara keseluruhan; (c) pokok materi: pokok-pokok materi menjadi judul dalam tiap BAB. Pokok materi dilengkapi pula dengan sub-sub materi yang dijelaskan sesuai dengan tujuan pembelajaran untuk setiap BAB; (d) latihan dan contoh soal: latihan yang ada dalam modul/bahan ajar mata kuliah matematika lanjut dilengkapi dengan kunci jawaban yang diletakkan setelah daftar pustaka dari produk yang dihasilkan. Adapun contoh soal untuk memberikan pemahaman dari materi pembelajaran yang dibahas.

\section{Memproduksi/Mengembangkan Bahan Ajar}

Langkah ketiga adalah memproduksi dan mengembangkan bahan ajar. Dalam memproduksi materi disusun sesuai dengan desain pengembangan produk yang telah dibuat. Produk yang dibuat berupa bahan ajar, terdiri atas lima BAB.

\section{Melakukan Evaluasi Produk}

Langkah ke empat adalah melakukan evaluasi produk berupa validasi ahli dan revisi. Para ahli melakukan uji validasi terhadap produk bahan ajar yang telah disusun. Proses validasi dilakukan oleh ahli materi dan ahli pembelajaran untuk menilai kualitas bahan ajar yang dikembangkan. Hasil dari validasi oleh dosen ahli materi dan ahli pembelajaran kemudian direvisi berdasarkan saran untuk perbaikan.

\section{Uji Coba Lapangan Skala Kecil dan Revisi}

Produk awal yang telah direvisi berdasarkan validasi para ahli kemudian diujicobakan kepada peserta didik secara terbatas pada mahasiswa clon guru Sekolah Dasar. Hal ini merupakan uji coba produk untuk mengukur kelayakan produk bahan ajar. Dalam uji coba lapangan skala kecil atau terbatas diambil beberapa orang mahasiswa untuk mengetahui tanggapan dan kendala-kendala yang dihadapi mahasiswa ketika menggunakan bahan ajar tersebut. Pengambilan subjek atau sampel untuk uji coba lapangan skala kecil dilakukan secara acak. Subjek dalam uji coba lapangan skala kecil sebanyak 6 orang mahasiswa yang representatif, dua mahasiswa mewakili kelompok bawah yaitu mahasiswa dengan prestasi rendah, dua mahasiswa mewakili kelompok tengah yaitu mahasiswa dengan prestasi sedang, serta dua mahasiswa mewakili kelompok tinggi yaitu mahasiswaa dengan prestasi tinggi. Pengambilan sampel mahasiswa yang representatif tersebut diambil secara acak berdasarkan data prestasi belajar mahasiswa. Hasil produk yang telah diujicobakan pada kelompok skala kecil dan telah diberikan penilaian dan saran subjek uji coba terbatas tersebut direvisi berdasarkan saran dari subjek uji coba. 
Uji Coba Lapangan Skala besar

Subjek dalam uji coba lapangan skala besar sebanyak 44 orang mahasiswa yang representatif yaitu mahasiswa dengan prestasi rendah, dua mahasiswa mewakili kelompok tengah yaitu mahasiswa dengan prestasi sedang. Uji coba lapangan skala besar bertujuan untuk mendapatkan penilaian untuk dijadikan bahan dalam penyempuraan. Produk bahan ajar bangun ruang sisi datar kemudian diuji cobakan dalam skala besar. Produk yang telah diujicobakan pada kelompok skala besar dianalisis saran yang diberikan kemudian dilakukan revisi produk bahan ajar. Hasil dari subjek uji coba dalam skala besar tersebut merupakan akhir dari revisi produk bahan ajar yang telah disusun.

\section{Data Uji Coba Produk}

Data Hasil Validasi Kelayakan Produk

Data yang berkenaan dengan penilaian responden atas kelayakan produk ini adalah data hasil validasi ahli dan hasil validasi ahli pembelajaran.

Data hasil validasi kelayakan produk ini berupa penilaian dan masukan dari aspek kelayakan isi, aspek penyajian materi, dan aspek pembelajaran. Data tersebut berupa skor yang selanjutnya dikonversikan menjadi nilai skala lima. Data validasi produk yang meliputi data validasi ahli mater dan data validasi ahli pembelajaran akan dipaparkan sebagai berikut.

Data Validasi Ahli Materi

Tabel 1. Skor Penilaian Ahli Materi ditinjau dari Aspek Kelayakan Isi

\begin{tabular}{|c|c|c|}
\hline No. & Indikator Penilaian & Skor \\
\hline 1. & $\begin{array}{l}\text { Kesesuaian materi yang disajikan } \\
\text { dalam bahan ajar dengan } \\
\text { Kompetensi mahasiswa }\end{array}$ & 4 \\
\hline 2. & $\begin{array}{l}\text { Ketepatan pemilihan materi yang } \\
\text { disajikan dalam bahan ajar }\end{array}$ & 5 \\
\hline 3. & $\begin{array}{l}\text { Kegiatan yang disajikan dalam } \\
\text { bahan ajar merangsang peserta } \\
\text { didik untuk aktif dalam } \\
\text { pembelajaran }\end{array}$ & 5 \\
\hline 4. & $\begin{array}{l}\text { Kegiatan yang disajikan dalam } \\
\text { bahan ajar menekankan pada } \\
\text { keterampilan proses }\end{array}$ & 5 \\
\hline 5. & $\begin{array}{l}\text { Kebenaran isi konsep yang } \\
\text { disajikan dalam bahan ajar }\end{array}$ & 5 \\
\hline & Skor Total & 24 \\
\hline & Rata-rata Skor & 4,8 \\
\hline & Kategori & $\begin{array}{c}\text { Sangat } \\
\text { Baik }\end{array}$ \\
\hline
\end{tabular}

Produk awal dikembangkan peneliti diberikan kepada ahli materi untuk divalidasi. Data dalam penelitian diperoleh dengan cara memberikan lembar penilaian kualitas bahan ajar yang mencakup aspek kelayakan isi. Ahli materi melakukan validasi produk didampingi pengembang, kemudian ahli materi memberikan tanggapan serta saran mengenai produk yang dikembangkan untuk langkah revisi. Adapun hasil validasi dari ahli materi dapat dilihat pada Tabel 1.

Skala penilaian kualitas bahan ajar oleh ahli materi diperoleh dari konversi data kuantitatif skala 5 yang tercantum dalam Tabel 1 . Validasi produk yang dikembangkan, oleh ahli materi tidak hanya skor penilaian skala 5 yang dikonversikan tetapi juga tanggapan, komentar, dan saran dari ahli materi tersebut untuk menjadi pedoman perbaikan produk. Saran Perbaikan dari ahli materi terhadap produk bahan ajar.

\section{Data Validasi Ahli Pembelajaran}

Tabel 2. Skor Penilaian Ahli Pembelajaran ditinjau dari Aspek Penyajian Materi Pembelajaran Matematika

\begin{tabular}{|c|c|c|}
\hline No. & $\begin{array}{c}\text { Indikator Penilaian Aspek } \\
\text { Penyajian Pembelajaran }\end{array}$ & Skor \\
\hline 1. & $\begin{array}{l}\text { Bahan ajar disajikan secara } \\
\text { sistematis }\end{array}$ & 4 \\
\hline 2. & $\begin{array}{l}\text { Penyajian bahan ajar menimbulkan } \\
\text { suasana keingintahuan mahasiswa }\end{array}$ & 4 \\
\hline 3. & $\begin{array}{l}\text { Kejelasan tulisan dan gambar dalam } \\
\text { bahan ajar }\end{array}$ & 5 \\
\hline 4. & $\begin{array}{l}\text { Penyajian bahan dilengkapi dengan } \\
\text { soal latihan }\end{array}$ & 5 \\
\hline 5. & $\begin{array}{l}\text { Gambar berhubungan } \\
\text { mendukung kejelasan konsep }\end{array}$ & 4 \\
\hline 6. & $\begin{array}{l}\text { Penyajian bahan ajar disajikan } \\
\text { secara runtut }\end{array}$ & 4 \\
\hline & Skor Total & 26 \\
\hline & Rata-rata Skor & 4,3 \\
\hline & Kategori & Baik \\
\hline
\end{tabular}

Data ini diperoleh dengan cara memberikan angket yang mencakup aspek penyajian materi terhadap produk bahan ajar. Ahli pembelajaran memberikan masukan tentang hal-hal yang berkaitan dengan produk yang dikembangkan dan memberikan masukan dan saran kepada pengembang untuk dipergunakan sebagai pedoman untuk melakukan revisi terhadap produk yang dikembangkan, yaitu produk bahan ajar bangun ruang sisi datar. Ahli pembelajaran melakukan validasi terkait dengan penyajian materi, ketertarikan pembaca terhadap materi yang ada dalam bahan ajar, kejelasan dan kesesuaian gambar sesuai dengan topik/materi yang 
dibahas. Gambar yang diberikan harus mendukung penguasaan konsep materi dan kemudahan mempelajari. Data hasil validasi ahli pembelajaran terhadap produk yang dikembangkan dapat dilihat pada Tabel 2.

Tabel 3. Saran Perbaikan

Ahli Pembelajaran dan Revisi

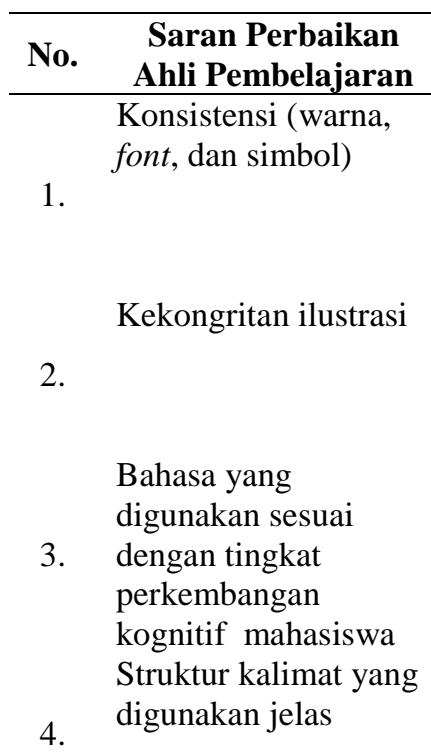

Bahasa yang digunakan

5. komunikatif

Kalimat yang digunakan sederhana

6. dan mudah dipahami

Mencantumkan alasan 7. tujuan pembelajaran

Memberikan

8.

pengantar materi

Mengurangi

keterangan-

9. keterangan yang

kurang bermakna

Revisi

Memperbaiki penulisan sehingga konsisten dalam font, warna, dan simbol

Memperbaiki ilustrasi dengan gambar-gambar yang lebih kongret

Memperbaiki penggunaan bahasa yang digunakan oleh mahasiswa

Memperbaiki kalimat-kalimat menjadi jelas dan mudah dipahami Memperbaiki bahasa yang digunakan sehingga menjadi lebih komunikatif Memperbaiki kalimat menjadi sederhana dan mudah dipahami mahasiswa.

Memperbaiki tujuan pembelajaran yang dengan form yang menyangkut $\mathrm{ABCD}$ Memperbaiki ilustrasi dengan gambar-gambar yang lebih kongrit Memperbaiki dangan mengurangi keteranganketerangan yang kurang bermakna

Data hasil validasi produk oleh ahli pembelajaran selain skor validasi penilaian yang memberikan penilaian pada aspek penyajian materi, terdapat beberapa saran dan masukan dari ahli pembelajaran tersebut untuk menjadi pedoman perbaikan produk. Saran Perbaikan dari ahli pembelajaran terhadap produk bahan ajar bangun ruang sisi datar, dapat dilihat pada Tabel 3.

\section{Data Uji Coba Kelompok Skala Kecil}

Produk bahan ajar yang telah divalidasi oleh ahli dan telah direvisi kemudian oleh pengembang, bahan ajar tersebut diujicobakan pada kelompok skala kecil yang terdiri atas enam orang peserta didik. enam orang peserta didik ini diberikan produk bahan ajar dan melakukan kegiatan sesuai dengan produk yang ada. Pelaksanaan uji coba kelompok skala kecil dilaksanakan sebagaimana kegiatan pembelajaran sesuai kompetensi yang.harus dicapai oleh mahasiswa. Data yang diperoleh dari uji coba kelompok skala kecil ini terdiri atas respon mahasiswa terhadap produk bahan ajar yang dikembangkan dan peningkatan keterampilan proses setelah mengikuti pembelajaran menggunakan bahan ajar yang dilihat dari pretest dan posttest.

\section{Respon Peserta Didik terhadap Bahan Ajar}

Data uji coba kelompok skala kecil yang menjadikan pertimbangan revisi produk salah satunya adalah respon mahasiswa terhadap bahan ajar yang digunakan dalam pembelajaran. Respon mahasiswa selama pembelajaran menggunakan bahan ajar dapat diketahui dari angket yang diberikan peneliti kepada enam subjek uji coba pada akhir pembelajaran. Respon mahasiswa meliputi aspek kelayakan isi, aspek penyajian, aspek kebahasaan, dan aspek kegrafikan. Data hasil respon mahasiswa pada uji coba kelompok skala kecil terhadap bahan ajar, secara ringkas disajikan dalam Tabel 4.

Tabel 4. Hasil Uji Coba Skala Kecil

\begin{tabular}{ccc}
\hline No Responden & Skor & Rata-rata Skor \\
\hline Mahasiswa 1 & 72 & 4,8 \\
Mahasiswa 2 & 70 & 4,67 \\
Mahasiswa 3 & 72 & 4,8 \\
Mahasiswa 4 & 68 & 4,53 \\
Mahasiswa 5 & 72 & 4,8 \\
Mahasiswa 6 & 70 & 4,67 \\
Rata-rata Skor & \multicolumn{2}{c}{4,71} \\
Kategori & \multicolumn{2}{c}{ Sangat Baik } \\
\hline Respon peserta didik terhadap bahan ajar
\end{tabular}
bangun ruang sisi datar dapat dilihat dari saran dan komentar subjek uji coba. Berikut ini saran dan komentar peserta didik subjek uji coba kelompok skala kecil secara umum. Hasil respon mahasiswa jika dibuat dalam bentuk grafik, dapat dilihat pada Gambar 2. 


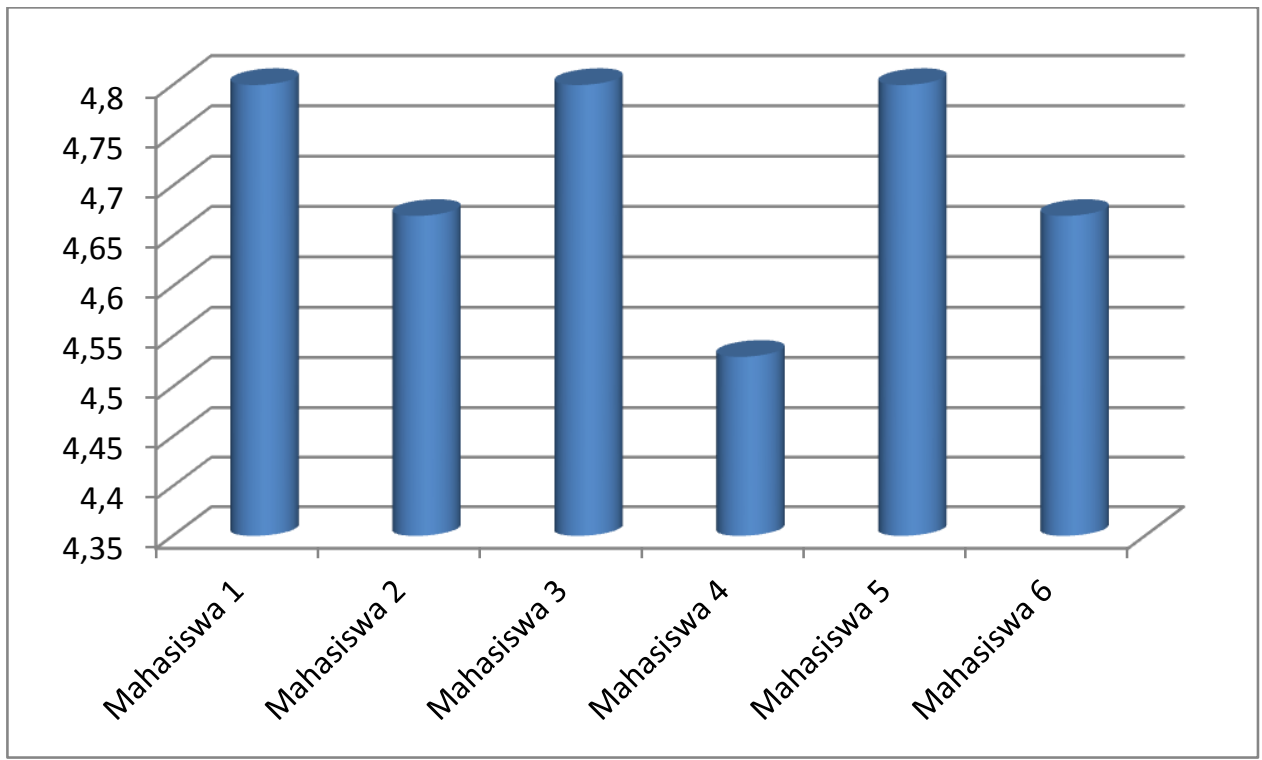

Gambar 2. Grafik respon Peserta Didik terhadap Bahan Ajar

Tabel 5. Hasil Pretest dan Posttest Uji Coba Skala Kecil

\begin{tabular}{cccccc}
\hline No. & Nama & Nilai Pretest & Nilai Posttest & Selisih & Gain standar \\
\hline 1. & Mahasiswa 1 & 87 & 95 & 8 & 0,62 \\
2. & Mahasiswa 2 & 85 & 90 & 5 & 0,33 \\
3. & Mahasiswa 3 & 77 & 85 & 8 & 0,35 \\
4. & Mahasiswa 4 & 78 & 80 & 2 & 0,09 \\
5. & Mahasiswa 5 & 67 & 80 & 13 & 0,39 \\
6. & Mahasiswa 6 & 71 & 85 & 14 & 0,48 \\
Rata-rata Nilai Ketercapaian & $\mathbf{7 7 , 5}$ & $\mathbf{8 5 , 8 3}$ & $\mathbf{8 , 3 3}$ & $\mathbf{0 , 3 8}$ \\
\hline
\end{tabular}

Keterangan: Selisih dihitung dari pengurangan nilai posttest dengan nilai pretest

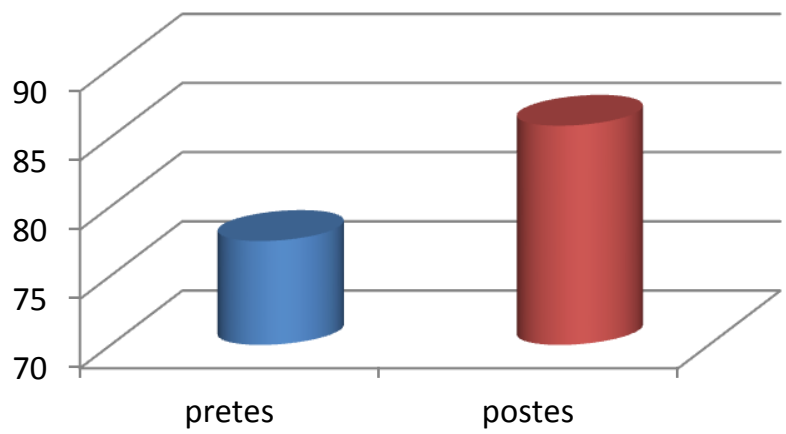

Gambar 3. Grafik Rerata Pretest dan Posttest pada Uji Coba Terbatas

\section{Ketercapaian Kompetensi Pembelajaran}

Ketercapaian peningkatan kompetensi mahasiswa dalam pembelajaran dapat dilihat dari nilai pretest dan posttest yang diperoleh mahasiswa. Untuk keperluan penelitian, mahasiswa yang diamati dalam uji coba terbatas hanya enam orang. Pemilihan ini didasarkan pada kemampuan mahasiswa, sehingga diperoleh mahasiswa berkemampuan tinggi, sedang, dan rendah. Hasil pretest dan posttest yang diperoleh dari 6 mahasiswa pada uji coba terbatas dapat dilihat pada Tabel 5 .
Gain standar dihitung menggunakan rumus sebagai berikut.

$$
\text { Gain Standar }=\frac{\text { Skor Postest }- \text { Skor Pretest }}{\text { Skor maksimum-Skor Pretest }}
$$

Adapun kompetensi mahasiswa dilihat dari pretest dan posttest dari penyelesaian soal latihan pada bahan ajar. Hasil rerata nilai pretest dan posttest pada uji coba terbatas jika dibuat dalam bentuk grafik, dapat dilihat pada Gambar 3 . 


\section{Analisis Data Hasil Validasi Kelayakan Produk}

\section{Analisis Data Hasil Validasi Ahli Materi}

Data yang diperoleh dari validasi ahli materi terhadap produk bahan ajar yang dikembangkan, dianalisis, dan digunakan acuan untuk melakukan revisi. Data validasi ahli materi tersebut diperoleh melalui angket penilaian ahli materi tentang kelayakan isi. Data pada Tabel 1 memperlihatkan bahwa bahan ajar hasil pengembangan ini dari aspek kelayakan isi/materi mendapatkan skor total 24. Skor total tersebut dikonversikan dengan tabel skala penilaian (Tabel 1) sehingga dapat dinyatakan bahwa bahan ajar bangun ruang sisi datar dari aspek kelayakan isi termasuk dalam kriteria "sangat baik" dengan rerata skor 4,8 .

Skor penilaian ahli materi terhadap kelayakan isi diantaranya kesesuaian materi dengan kompetensi yang harus dicapai oleh termasuk mahasiswa "baik" dengan skor 4. Ketepatan pemilihan materi yang disajikan dalam bahan ajar termasuk kriteria "sangat baik" dengan skor 5. Kegiatan yang disajikan dalam bahan ajar merangsang mahasiswa untuk aktif dalam pembelajaran termasuk kriteria "sangat baik" dengan skor 5. Kegiatan yang disajikan dalam bahan ajar termasuk kriteria "sangat baik" dengan skor 5. Kebenaran isi konsep yang disajikan dalam bahan ajar termasuk kriteria "sangat baik" dengan skor 5. Skor penilaian ahli materi terhadap aspek kelayakan isi dapat dilihat pada Tabel 6 .

Tabel 6. Distribusi Frekuensi Penilaian Ahli Materi pada Aspek Kelayakan Isi

\begin{tabular}{ccc}
\hline \multirow{2}{*}{ Kriteria } & \multicolumn{2}{c}{ Aspek Kelayakan Isi/Materi } \\
\cline { 2 - 3 } & Frekuensi & Persentase \\
\hline Sangat Baik & 4 & $80 \%$ \\
Baik & 1 & $20 \%$ \\
Cukup Baik & 0 & $0 \%$ \\
Kurang Baik & 0 & $0 \%$ \\
Sangat Kurang & 0 & $0 \%$ \\
Jumlah & 0 & $100 \%$ \\
\hline
\end{tabular}

Tabel 6 menunjukkan bahwa distribusi penilaian ahli materi terhadap aspek kelayakan isi terdapat $80 \%$ yang termasuk kriteria "sangat baik" dan 20\% termasuk dalam kriteria "baik".

\section{Analisis Data Hasil Validasi Ahli Pembelajaran}

Data yang diperoleh dari validasi ahli pembelajaran terhadap produk bahan ajar bangun ruang sisi datar yang dikembangkan, dianalisis, dan digunakan sebagai acuan untuk melakukan revisi. Data validasi ahli pembelajaran tersebut diperoleh melalui angket penilaian ahli pembelajaran yang terdiri atas 6 pokok penilaian. Data pada Tabel 6 memperlihatkan bahwa bahan ajar bangun ruang sisi datar hasil pengembangan ini dari aspek penyajian materi pembelajaran mendapatkan skor total 26. Skor total tersebut dikonversikan dengan tabel skala penilaian (Tabel 1) sehingga dapat dinyatakan bahwa bahan ajar bangun ruang sisi datar dari aspek penyajian materi termasuk dalam kriteria "sangat baik" dengan rerata skor 4,3.

Data skor penilaian kualitas bahan ajar bangun ruang sisi datar oleh ahli pembelajaran menimbulkan suasana keingintahuan dan untuk kriteria dukungan kejelasan konsep termasuk dalam kriteria "baik" dengan skor 4. Kejelasan tulisan dan gambar, Penyajian bahan ajar bangun ruang sisi datar dilengkapi dengan gambar dan ilustrasi, dan penyajian bahan ajar bangun ruang sisi datar disajikan secara menarik. Ahli pembelajaran menilai bahwa produk ini termasuk dalam kriteria "baik" dengan skor 4. Adapun penilaian ahli pembelajaran terhadap aspek penyajian materi pembelajaran menunjukkan bahwa kemenarikan gambar atau ilustrasi yang dimuat dalam produk, desain bahan ajar bangun ruang sisi datar termasuk kriteria "sangat baik" dengan skor 4,3. Selain itu penggunaan huruf dalam produk bahan ajar bangun ruang sisi datar menurut penilaian ahli pembelajaran termasuk kriteria "baik" dengan skor 4. Secara ringkas skor penilaian ahli materi dan ahli pembelajaran dapat dilihat pada Tabel 7.

Tabel 7 menunjukkan bahwa distribusi penilaian ahli materi dan ahli materi dan ahli pembelajaran termasuk kriteria "baik" dan 50\% termasuk dalam kriteria "baik".

Tabel 7. Distribusi Frekuensi Penilaian Ahli Materi dan Ahli Pembelajaran

\begin{tabular}{|c|c|c|c|c|}
\hline \multirow[t]{2}{*}{ Kriteria } & \multicolumn{2}{|c|}{ Ahli Materi } & \multicolumn{2}{|c|}{$\begin{array}{c}\text { Ahli } \\
\text { Pembelajaran }\end{array}$} \\
\hline & Frek & Persentase & Frek & Persentase \\
\hline Sangat Baik & 0 & $0 \%$ & 0 & $0 \%$ \\
\hline Baik & 4 & $50 \%$ & 4 & $50 \%$ \\
\hline Cukup Baik & 4 & $50 \%$ & 4 & $50 \%$ \\
\hline Kurang Baik & 0 & $0 \%$ & 0 & $0 \%$ \\
\hline $\begin{array}{l}\text { Sangat } \\
\text { Kurang }\end{array}$ & 0 & $0 \%$ & 0 & $0 \%$ \\
\hline Jumlah & 8 & $100 \%$ & 8 & $100 \%$ \\
\hline
\end{tabular}

\section{Analisis Data Hasil Uji Coba Kelompok Skala Kecil}

Data pada tabel menampilkan bahwa respon mahasiswa terhadap bahan ajar bangun ruang sisi datar yang dikembangkan dalam 
perkuliahan matematika lanjut rerata skor yang diperoleh dari data respon mahasiswa berada pada ketegori "sangat baik", sehingga dapat dinyatakan bahwa sebagian besar mahasiswa subjek uji coba kelompok skala kecil sangat setuju dengan penggunaan bahan ajar bangun ruang sisi datar yang dikembangkan peneliti dalam pembelajaran.

Adapun untuk revisi produk pengembangan dilakukan berdasarkan saran ahli materi dan ahli pembelajaran, serta temuan di lapangan yaitu pada saat uji coba kelompok skala kecil. Revisi produk pengembangan dilakukan berkalikali untuk menyesuaikan dengan kompetensi yang harus dicapai oleh calon guru sekolah dasar.

\section{Analisis Data Hasil Uji Coba Kelompok Skala Besar}

Data hasil uji coba dalam kelompok skala besar menampilkan bahwa respon mahasiswa terhadap bahan ajar bangun ruang sisi datar yang dikembangkan dalam perkuliahan matematika lanjut perlu direvisi dan dibuat lebih baik lagi.

Tabel 8. Rentang Penilaian Mahasiswa dalam Produk Bahan Ajar

\begin{tabular}{ccc}
\hline Rentang Skala & Frekuensi & \% \\
\hline $50-60$ & 9 & 20,455 \\
$61-70$ & 21 & 47,727 \\
$71-80$ & 11 & 25 \\
$81-90$ & 3 & 6,8182 \\
& $\mathbf{4 4}$ & $\mathbf{1 0 0}$ \\
\hline
\end{tabular}

\section{Kajian Produk Akhir}

Bahan ajar bangun ruang sisi datar telah selesai dikembangkan. Tahapan-tahapan menganalisis kebutuhan, mendesain pengembangan, memproduksi/mengembangkan bahan ajar, melakukan evaluasi produk, dan melakukan uji coba produk akhir pengembangan telah dilakukan yaitu kajian produk akhir pengembangan bahan ajar bangun ruang sisi datar merupakan hasil konfirmasi antara teori dan penemuan penelitian sebelumnya dengan hasil penelitian yang diperoleh. Kajian produk akhir dalam pengembangannya merujuk pada literatur yang berisi konsep yang dapat dipertanggungjawabkan.

Penilaian produk bahan ajar bangun ruang sisi datar menunjukkan hasil yang positif. Hasil penilaian ahli materi dan ahli pembelajaran hasil pengembangan termasuk dalam kategori "baik". Hasil penilaian itu menunjukkan bahwa bahan ajar bangun ruang sisi datar hasil pengembangan tersebut memiliki kemudahan penggunaannya dalam pembelajaran.

Produk akhir bahan ajar bangun ruang sisi datar diperoleh setelah mengalami uji coba kelompok skala kecil. Produk bahan ajar bangun ruang sisi datar telah melalui proses penilaian kualitas oleh ahli materi dan ahli pembelajaran, selanjutnya direvisi sesuai saran. Produk hasil revisi tersebut diujicobakan pada subjek uji coba kelompok skala kecil.

Berdasarkan rerata skor yang diperoleh dari data respon mahasiswa menghasilkan rerata skor lebih dari 4, sehingga dapat dinyatakan bahwa sebagian besar mahasiswa sebagai subjek uji coba kelompok skala kecil sangat setuju dengan penggunaan bahan ajar bangun ruang sisi datar yang dikembangkan peneliti dalam pembelajaran.

\section{SIMPULAN}

Berdasarkan hasil penelitian dan pengembangan, dapat disimpulkan beberapa hal yaitu: (1) langkah-langkah yang paling efektif dalam mengidentifikasi pengembangan bahan ajar bangun ruang sisi datar adalah menganalisis kebutuhan, mendesain pengembangan, memproduksi/mengembangkan bahan ajar, melakukan evaluasi produk, dan melakukan uji coba produk akhir; dan (2) kualitas bahan ajar bangun ruang sisi datar yang dikembangkan menurut penilaian ahli materi termasuk kriteria "sangat baik" dengan rerata skor 4,8 , menurut ahli pembelajaran termasuk kriteria 'baik' dengan rerata skor 4,3

\section{DAFTAR PUSTAKA}

Chambers, P., \& Timlin, R. (2013). Teaching mathematics in the secondary school. Thousand Oaks, CA: SAGE.

Depdiknas. (2008). Pedoman pelaksanaan materi pembelajaran dan pengembangan pembelajaran contextual (CTL) sekolah menengah pertama (SMP). Jakarta: BP Cipta Jaya.

Depdiknas. (2008). Panduan pengembangan bahan ajar. Jakarta: Depdiknas.Gall, M. D., Gall, J. P., \& Borg, W. R. (2007). Educational research: An introduction. Pearson/Allyn \& Bacon.

Kidd, W., \& Czerniawski, G. (2010). Successful teaching 14-19: theory, practice, and reflection. New Delhi, India: Sage.

Manfaat, B. (2010). Membumikan matematika: Dari kampus ke kampung. Cirebon: PT Buku Kita. 
Matutina, J. A. (2014). Pengembangan lembar kerja siswa mata pelajaran matematika materi bentuk aljabar dengan pendekatan kontektual untuk siswa SMP kelas VII. Universitas Negeri Yogyakarta. Retrieved from http://eprints.uny.ac.id/13206/

Satrianawati, S. (2015). Pengaruh penggunaan model problem-based learning dan project-based learning terhadap kemampuan penalaran dan sikap siswa pada matematika di kelas IV SD Kanisius Demangan Baru 1 Yogyakarta dalam implementasi Kurikulum 2013. Universitas Negeri Yogyakarta. Retrieved from http://eprints.uny.ac.id/14205/

Sukmadinata, N. S. (2013). Metode penelitian pendidikan. Bandung: PT Remaja Rosdakarya.

The National Council of Teachers of Mathematics. (2000). NCTM principles and standards for school mathematics, Association Drive, Reston, VA: Library of Congres Cataloguing-in-Publication Data. Retrieved from https://www.nctm.org/store/Products/NC TM-Principles-and-Standards-for-SchoolMathematics,-Full-Edition-(PDF)/ 